\title{
Non-timber forest products from community forestry practices, problems and prospects for livelihood strategy in Jumla
}

\begin{abstract}
Mohan Paudel ${ }^{1}$
Jumla is highly rich in its vast and valuable Non-Timber Forest Products (NTFP) including different kinds of valuable medicinal and aromatic plants. However, in recent years, a significant decrease in availability of commercially traded NTFP species has been experienced. Nevertheless, some important initiatives have also been started to manage NTFPs in a sustainable basis. Community Forestry (CF) is one of these. This study aims to suggest practical and sustainable NTFPs management approach in Jumla analyzing existing roles in livelihood strategy. Study covers CFUGs in Eastern part of the district comprising about $70 \% \mathrm{CF}$ area and contributes more than $60 \%$ of exported NTFPs. PRA and RRA tools were used for data collection in the field. NTFPs were found an integral part of the livelihood strategy in the district. More than $90 \%$ food deficit people $(57 \%)$ were having income from NTFPs as a second source of food arrangement to sustain their livelihood. The average annual income from NTFPs per HH was 18,565. No significant correlation was observed between different social groups and income from NTFPs. But, male were found mostly involved in NTFPs collection comparing female. Beside some promising efforts towards control harvesting of NTFPs, no significant impact of CF was observed. Awareness level of the users and governance aspect of CFUGs were found very poor. There was huge gap between management objectives and management prescriptions of most of the community forests.
\end{abstract}

Key words: NTFPs, Livelihood, management, CFUGs

$\mathrm{J}$ umla is one of the remote and Himalayan districts in the Karnali Zone of Nepal. Altitude ranges trom 2076 m. to 6387 m. from Mean Sea Level. District headquarter Khalanga is located almost in the centre of the district. It is divided into 30 VDCs. Air service from Nepalganze and Surketh is only the way of access to this district so far. Jumla is characterized by acute poverty and illiteracy with high growth rate of population. Agricultural production in the high hills and mountains are insufficient to sustain the livelihood of growing population (CECI 1997). The situation is not so much different in Jumla. It is defined as a food deficit district.

Nevertheless, Jumla is known as a rich district for its highly diversifying natural resources. It is highly rich district in its vast and valuable Non-Timber Forest Products (NTFP) including different kinds of valuable medicinal and aromatic plants. About $41 \%$ of the district area is covered by the forest and rangeland. Not only the dense forest; steep rocks, open rangelands and seasonal snow lands are also equally important consisting different types of
NTFPs with them. People are using NTFPs especially the medicinal and aromatic Plants (MAP) as an alternative source of income. NTFPs play a crucial role in the livelihood strategy of these people (Subedi 2003). YarchaGumba (Cordyceps Sinensis) for example, is one of the most valuable NTFP find in open rangeland cover with snow in winter. Other important NTFPs that are found and traded from Jumla are Morel (Morchella Conica) called Guchchi Chau, Jatamasi (Narostachys Grandifolia), Sugandhawal (Valeriana Wallichii), Atis (Delphinium Himalayai), Nirbishi (Pernacia Nubicola) etc. According to the District Forest Office (DFO), in average, 16 hundred thousands rupees of royalty are collected from hundreds of tons of different NTFPs exported from the district annually.

Community Forestry (CF) is one of the major initiatives to manage natural resources with active involvement of resource dependent people of Nepal. Because of $\mathrm{CF}$, total growing stock and the level of regeneration has increased and improved overtime. The program has also impacted positively on building 
local institutions. If CFUGs mobilize in proper way, they can be the most appropriate institution for local development that can be used by the other line agencies besides forestry. The program has also social and economic status of the local users. It has given emphasis on empowering the women, poor, and the disadvantaged groups. Most of the CFUGs have increased employment and income in rural areas mostly through the NTFPs (MFSC 2004). To some extent, similar impacts of CF have also been observed in Jumla too. So far, more than $13 \%$ of the total forest area i.e. 15445 ha has been handed over to the 105 CFUGs in Jumla. In the recent years, some Community Forest User Groups (CFUG) have also generating income from their forest exporting NTFPs.

\section{Problem statements and justifications}

In recent years, a significant decrease in availability of all NTFPs and especially those of commercially traded species has been experienced in Jumla. DFO records since last few years indicate that production capacity of the forest has gradually been decreased. For example, 124 tons of Jatamasi exported in 2056 was reduced to 37.7 tons in 2058 and further reduced to 28 tons in 2063. The same trends have also been observed with other species too. Informal reports from the collectors and entrepreneurs have also justified that the valuable resources are being depleting day by day.

But however, collection and trade of NTFPs cannot be controlled partly because of administrative difficulties and largely because it is only the main source of cash income for the local people (Bhandari 2003). If this trend continue, it would create sever threat to the depletion of valuable NTFPs. Apart of negative ecological consequences, it will also have socioeconomic consequences in the district. Poor collectors will lose their traditional livelihood assert loosing goods and services. Moreover, the whole district will lose its identity of rich in natural diversities.

Therefore, without delaying, it is time to identify root causes of resource depletion indeed. On the basis of which appropriate management modalities should be developed and implemented effectively. But, it doesn't mean that no thing has been done so far. Several initiatives for effective resources management have already been implemented and shown promising result too. CF and Leasehold Forestry (LF) are major initiatives with promising impacts in Jumla district too. Besides the conservation efforts, CFUGs have initiated some important efforts to raise the economic status of the resource poor people through collection and marketing on some known NTFPs

However, some gaps have been realizing between CF management practices and its goal towards sustainability. Different authors i.e. Subedi, 2003; Bhandari, 2003; Gurung \& Pandey, 2003; Ojha et al, 2003 and MFSC, 2004 have also reported same experiences from their studies in different parts of Nepal including Jumla. The CF programs' livelihood contribution to the poor, women and disadvantage groups has not been so successful. The major part that CF should effectively address in this district are livelihood and equity; governance; sustainability; high altitude forest management; and revenue sharing among. It is often observed that local elite make the decision and make capture most of the benefits from the forest. And as a result, different doubt and debates have also been coming up regarding existing approach of $\mathrm{CF}$ to achieve goal.

Further more, it is urgent to assess existing practices and analyze issues thoroughly. Root causes behind the doubt and debates that might have resulting CF not being as much effective as expected should be assessed and analyzed. Existing CFUGs operation plan should be reviewed and adjusted addressing the needs and interests of poor, women and disadvantages in the group.

This study aims to assess and evaluate all of those issues experienced indeed. It has assessed and analyzed cause and effect relationships behind the success and failure impression of CFUGs in Jumla. Findings indicate gaps between the needs and interests of women, poor, disadvantages groups (defined as gender) and existing practices of CFUGs management. Moreover, research findings suggest practical and possible ways of CFUG to promote rural livelihood towards income generation through sustainable management of NTFPs.

\section{Objectives}

The main objective of this study is to suggest practical and sustainable NTFPs management approach through Community Forestry analyzing its roles in existing livelihood strategy in Jumla. Specifically, study aims as follows:

- To assess importance of NTFPs on the rural livelihood strategy in Jumla. 
- To assess and analyze interrelationship between gender (sex, cast, ethnic groups) and their access to NTFPs for income generation in Jumla.

- To assess and evaluate existing CF practices in the field of sustainable NTFP management in Jumla.

- To identify gaps towards sustainable management of NTFPs through CF in Jumla.

\section{Methods and Materials}

\section{Study area:}

Regarding availability and trading potential of NTFPs, study was conducted in different CFUGs located Eastern upper land of the Jumla district. According to the DFO Jumla, more than $60 \%$ of the exported NTFPs come from the study area. Map 1 given below shows coverage and location of the study area in the District.

Map 1 showing study area in shade

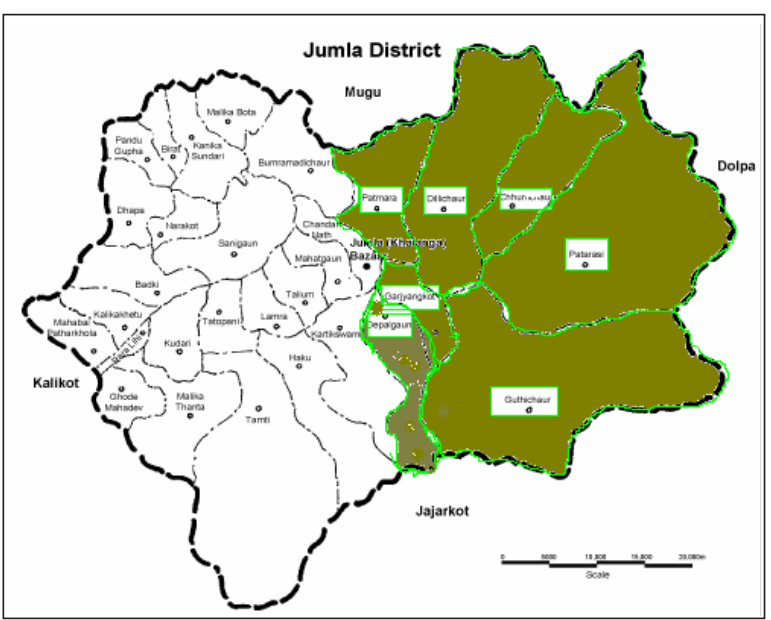

Data collection and analysis methods

Out of the total CFUGs in the study area, more than $50 \%$ (23) were randomly selected for the purpose of data collection visit. Study team comprising an expert with two rangers and local mobilizers collected required information in the field using different PRA and RRA tools. CFUGs operation plans and their other related documents were reviewed. District Forest Office and other related social groups and NGOs were also consulted to get required information to meet the objectives of the research.

Analysis of the data started with organizing them in tabular forms in excel working sheet. Using the same software, data were categorized according to their compatibility to the designed questions. Final results were presented in the form of different charts and figures with appropriate analysis. Analytical discussions were also performed regarding relevancy and validity of the findings on the basis of which research was concluded with some recommendations.

\section{Result and Discussion}

This section presents the study findings with appropriate discussions comparing other related (and available) findings published. Different tests and comparisons have been made to meet objectives answering designed questions.

\section{Importance of NTFPs in the livelihood strategy}

Forest resources are an integral part of the livelihood support in Nepal, where overwhelming majority people live in the interface between forest and agriculture. There are very few economic opportunities for the population of the hills and mountainous areas. NTFPs play a crucial role in the livelihood strategy of these people (Subedi, 2003). Findings of this research totally support the statement above.

Figure 1

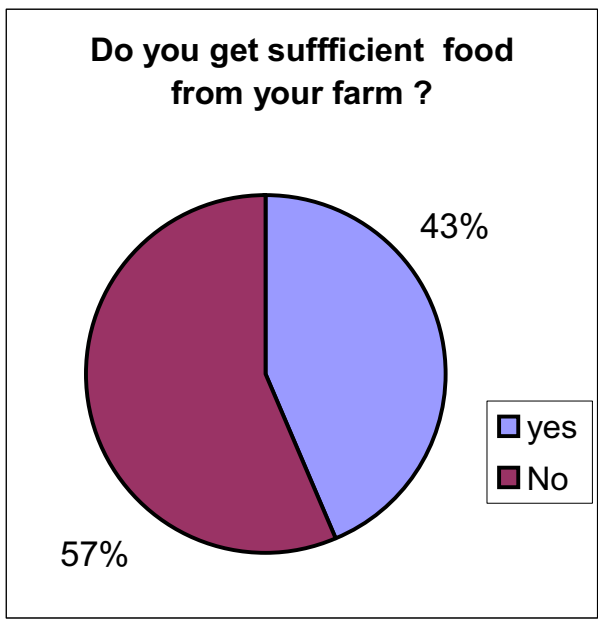

Figure 2

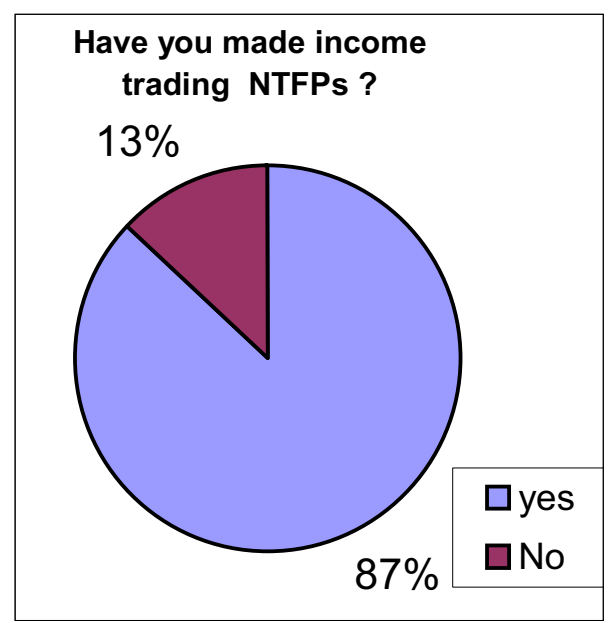


Figure 1 shows that $57 \%$ of the total households $(\mathrm{HH})$ are living under food deficit from their farm production. To meet rest of the needs, most of them (>90\%) are getting income from NTFPs as a second alternative to sustain their livelihood. However, it does not mean that only food deficit $\mathrm{HH}$ involve trading NTFPs. Figure 2 shows that $87 \% \mathrm{HH}$ of the study sites have been involving in this business. It clearly indicates that not only the poor (food deficits) are involving but the people having sufficient food from their farm are also equally tapping the NTFPs as an indifference part of their livelihood strategy. Similar finding was reported by the Gurung and Pandey 2003. According to them, in the most of the study areas, people collect NTFPs as main income source and land lord people also involved in this field. The average annual income from NTFPs per $\mathrm{HH}$ is 18,565 Rupees in the study area. However, according to the respondents from Dillichaur, Patrasi and Guthichaur, annual income from NTFPs ranges from 5000 to 1 , 50,000 Rupees. But it is not same in lower villages like Depalgaun and Garjangkot. Basically, it is because of the distance between the village and the most valuable resource like Yarcha, Guchhi and Jatamasi (Vulte) to be collected. And second important factor is family size. Bigger the family size, more the income from NTFPs.

\section{NTFPs collectors and their respective gender}

Based on the responses of the semi structured interview, interaction and other verified indicators in the field, NTFPs and its gender aspect was scaled as a measure of interrelationship between them in course of livelihood strategy. Comparing both figures given above (1\&2); one can easily understand that NTFP is the second source of food arrangement. NTFPs contribute about 30 to $40 \%$ food and 60 to $70 \%$ other livelihood asserts in the study area. However it differs in different villages. It is only the way of making cash income for most of the people living high altitude and near to the natural habitats of most of the valuable NTFPs (MAPs). For example, livelihoods in Patrasy, Dillichaur and Guthichaur VDCs in the study area are more depended in NTFPs comparing Depalgaun and Garjyangkot.

However, figures above do not make clear whether specific cast, sex and other types of social groups (gender) have specific association with NTFP collection and other related activities or not. Looking at sex, more then 95\% NTFP collectors in the study site are male. It is basically because of the distance (more than at least two days walking) from the village and work division between male and female in $\mathrm{HH}$ level. Women look after the children, kitchen and other farm related activities and as a result they can not leave home for long time and collection of NTFPs need at least 15 days even for the nearest village to the collection sites. However in low altitude, women and children also collect some NTFPs. Guchichau (Mushroom) is one of them. Similar findings were reported by Pandey 2000 and Edward 1996 too.

Regarding other aspects of gender association with collection and trade of NTFPs, figure 3 given below shows average annual income generated by different cast groups from NTFPs. Average annual income made by the marginalized group (also called lower cast) is less then the average of total in the study area. It indicates no significant correlation between lower cast people and NTFP collectors. However, it doesn't mean this result totally contradicts with the report by Subedi, 2003. He has reported that most of the NTFP collection is done by the poor and marginalized. Still, about $42 \%$ of them are making money more than average of the area in total. Despite this, finding does not indicate that the governing factor in this regard is social discrimination like cast.

Figure 3

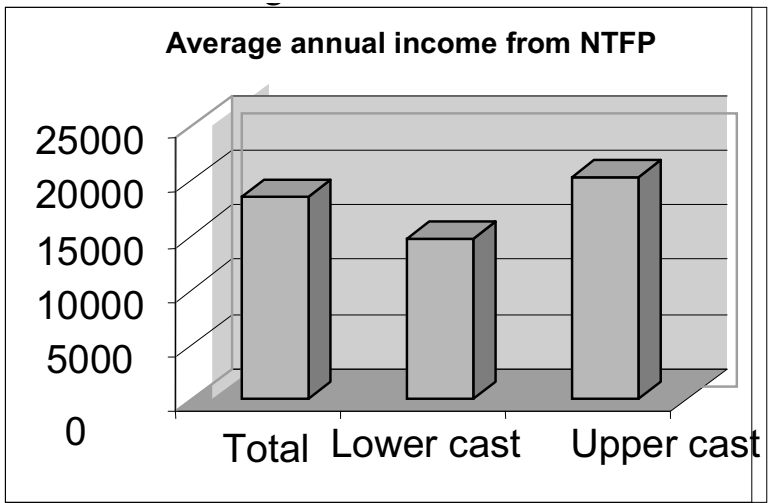

Instead, family size and distance between village and collection sites are found major governing factors. Looking at Patracy, Dillichaur and Guthichaur VDCs, average income made by lower cast is not below the average but it is in Depalgaun and Garjangkot. In these VDCs, although they know very well about the income from NTFPs, normally, they do not want to leave their traditional livelihood system i.e. ironsmith and tailoring along with other labor works in the village. In these areas, people having more livestock 
are found earning more money from NTFPs. In high altitude, shepherds harvest NTFPs simultaneously with pastoral practices. Gurung and Pandey (2003) have also reported that shepherds collect more NTFPs than other people. However, people in the study area reported that most of them (shepherds) harvest premature plants during pastoral period (rainy season). Jatamasi and Yarchagumba are the species mostly the shepherds collect and make handsome money. And the upper cast groups normally own more livestock comparing lower cast.

\section{Existing CF practices and sustainability issues of NTFPs}

Governance: Several authors and /or institutions working at $\mathrm{CF}$ and related field have often reported that CF has initiated great effort towards sustainable management of NTFPs boosting income of resource dependent poor, women and marginalized users. Bhandari 2003, Gurung and Pandey 2003, and USAID 2003 have reported similar situation in Jumla district too. However, result of the study does not totally support the argument indeed. Figure 4 and 5 given below show how decisions are made by FUGs as an indicator of existing governance status in the study area.

Figure 4



Figure 5

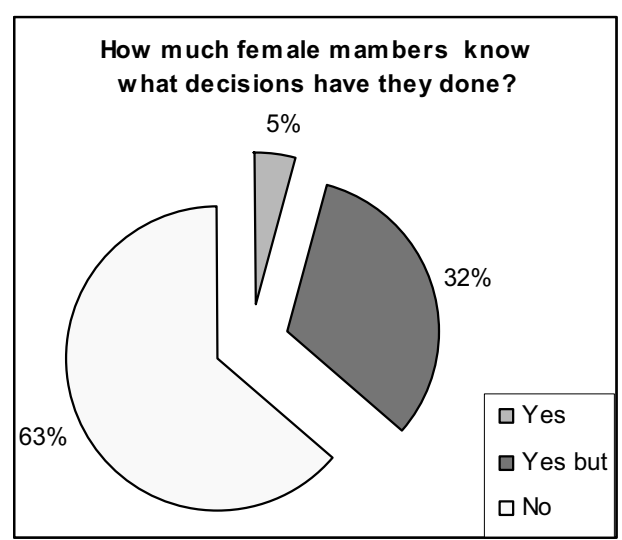

Most of the decisions in $48 \%$ of the total CFUGs are made by the chairman. 14\% CFUGs are found completely functionless where no decisions are made. $38 \%$ of them are making decisions by the committee. Regarding social inclusion, in average, 25 to $40 \%$ committee members are female. Different social groups are also found to be included according to their population size within the groups. However, they were found to be included just for the shake of inclusion. Especially female members were found largely unknown about the policies and plans of their own. Most of the female members were even unknown what rights and responsibilities do they have. Figure 5 shows their level of understanding. Result was drawn on the basis of interaction with female members of sample CFUGs. $63 \%$ of them easily replied that they do not know what decisions have been written in their minute book at their last meeting. Normally, they do not take part in the meeting (instead, their husbands attend the meetings) but their names are registered and signs are taken bringing minute books into home. Only 5\% female members were found to be taking part regularly with influential role. Most of them were either chairman or secretary of the committee. Despite talking part in the meeting, $32 \%$ of the female members can't either express their views or convinced other members towards their concerned and as a result they remain passive.

\section{Resource condition and management practices:}

Figure 6 and 7 given below show existing resource condition, management plans and practices of NTFPs in the study sites. Looking at figure 6, 35\% CFUGs still comprise considerable resources (NTFPs) in their forest. Out of them, 8\% CFUGs think that they have still enough resources. Lumteli and Syalapatal CFUGs for example think if they restrict outsiders (from other VDCs) to collect NTFPs, they will never have resource crisis'.

Figure 6




Figure 7

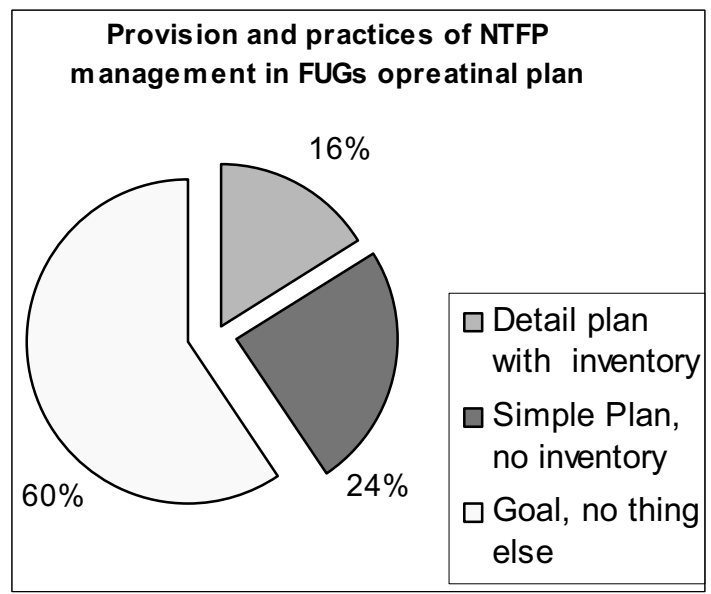

$27 \%$ of them however think that they are losing their resources because of uncontrolled and unscientific harvesting practices. But it does not mean that rests of them do not worry about. All respondents $(100 \%)$ in the field were expressing their concern about resource degradation in the district. 24\% CFUGs are not taking NTFPs as a major resource to be managed in their forest though their forest consists some of the most valuable species like Guchichau (morel). Most of such FUGs are in Depalgaun and Garjangkot area. 41\% CFUGs in the study area are lacking any valuable NTFPs naturally but most of them have potential to cultivate. And cultivating some valuable NTFPs in community forests has already been started in Jumla. Jatamasi and Kutki domestication have successfully been tested through research undertaken by different projects. For example Dabur Nepal recommended Kutki and Jatamasi as the most potential species to be domesticated.

Figure 7 given above shows how the FUGs are practicing towards management of NTFPs through their management plan. 16\% CFUGs have their management plan with detail of the resource condition and harvesting prescriptions. They have started issuing harvest and export order in accordance with their approved plan. According to the secretary (B.B. Sarki) of Lumteli CFUG, Lumteli have earned more than 3 lakhs rupees trading NTFPs since it's handed over time (five years before) but because of political crisis (Maoist) they have lost most of it. They can't even say where they have spent that much money. Similar situations were observed in other CFUGs too.

$24 \%$ CFUG's management plan consist simple description about NTFP harvesting including price of some major species. But most of them are lacking resource information, annual allowable harvesting quantities etc. They have not yet started taking responsibilities over it. Immature and haphazard collections have also been going on. And as a result degradation of some valuable species like Jatamasi and Kutki is going on. Several other studies (Edward 1994, 1996a, 1996b, Malla et al 1995, Hertog 1995, Karki 1996, Sharma 1996, Subedi 1997) have also reported similar findings that certain NTFP species or groups of species are being overused and degraded. According to them the reasons for this degradation are complex but include the lack of knowledge and local control over these resources, rural poverty, increasing external market demand and social and cultural tradition.

Despite intangible descriptions, $60 \%$ management plans in the area are completely silent about the NTFPs. It means, majority of the handed over community forests are either lacking NTFPs or they are unaware about it. Looking at the total CF area $(13 \%)$, one can easily understand that very little forest area has handed over to the FUGs so far. Most of the $\mathrm{CF}$ areas are sporadic small patches of forest near to the villages that are primarily been managed to get basic household needs rather than income generation. More than that, most of the area consisting valuable NTFPs are far from the village and are still under the government management.

Hobley \& Shah (1996) have given higher priority on users' knowledge as an indicator of groups' effectiveness. Poor awareness level of users' in the study area is another underlying reason behind the silent feature of CF management plans towards NTFP management. Majority of the committee members do not know that they have rights to harvest and trade NTFPs. They think, only the DFO is authorized to give collection and release permit. Apart of this, price always found to be fluctuated. And as a result, markets remains unstable, unpredictable and irregular. Pandey and Gurung (2003) have also reported similar findings from different parts of Nepal including Jumla. According to them the price fluctuation affects to all involved in this business. No body feels secure. Sometimes local collectors get high benefit and middlemen are in loss and in other time vice versa. The marketing of NTFPs are fully controlled by external demands, which is the prime reason for its uncertainty. And as a consequence, no enthusiasm towards development of NTFPs has resulted in the CFUG level. 
Different social aspects of community forestry are connected each other (they are not completely independent) with cause and effect relationship. Better awareness increases good governance; good governance promote ownership and willingness. Willingness explores different options towards development and sustainable management of the resources. From the above, it is clear that governance and gender inclusion aspects of CFUGs in the study area are weak. Most of the members including female and marginalized groups are passive and as a result groups are either not functioning properly or elites are doing what they want. Such conditions prevent feeling ownership and ultimately, resources are mismanaged towards overuse and degradation. In that situation community forestry will only contribute to the reproduction of rural poverty and lead to division and disharmony among those affected (Ostrom, 1999).

\section{Gaps between objectives and practices of $\mathrm{CF}$ in the study area}

One of the main aims of resource management is the avoidance of resource degradation. In this regard, resource management goals should be a level of ecological sustainability "that gives future generations the option to continue such management or liquidate the resource" (Bromley, 1996 cited in Pokheral 1998). Looking at goals and objectives of the CFUGs in the study area, all of them are aiming to manage forest resources to meet needs and interests of the users in a sustainable basis through different activities of protection and development. In addition to timber and fuel wood, almost all of them aim to manage NTFPs. Even more, NTFPs are given high priority sector of management for income generation. However, ground realities of existing practices don't support those written objectives. Figure 7 makes it clearer. Despite written objectives, 60\% CF operational plans in the study area are lacking any activities related to protection, development and management of NTFPs. It means, running practices are not guided by the management guidelines which can be considered as a major gap between the goal and the ground reality.

Sustainable CF is essentially about sustainable management of resource and resource dependent people. Society depends on forest for number of goods and services. The forest has to serve as a resource to supply goods and services required by the society and for the maintenance of the production potential of the ecosystem are necessary. The two way interaction determines the relationship between forest ecosystem and the society. In this sense, the meaning of sustainable management of forest is simply the sustainability of that interrelationship.

However, ground reality in most of the CFUGs indicates no consideration about the interrelationship between social and ecological part of the CF. In one hand, looking at figure $4 \& 5$, awareness and governance level of the user groups are poor and discriminating. Majority of the users are unaware about the rights and responsibilities of them and as a result few influencing elites are making their own decision neglecting needs and interests of majority resource dependents. On the other hand, figure $6 \&$ 7 indicate that there are either plenty of resources or potential to develop but in reality ongoing practices are not matching to what should have done. Objectives have been stetting without proper resource assessment. People are making their efforts to harvest NTFPs in their own way, unscientifically; especially the local herbal collectors and traders are involved in such unsustainable exploitations. Pandey (2000) has also reported similar finding that the local inhabitants in the remote mountains are unaware of the facts that they are going to loose their inherited natural resources as the source of income very soon. From the above, it is very much clear that there is a big managerial gap in between the needs and interests of the groups and the resources they have to manage to meet objectives. In addition, gaps have not only been experienced in users' level, it has also realized in the level of supporting stakeholders (GOs and NGOs). Technical supports that should have provided by the DFO have not been performed properly and timely. Users could not get required knowledge and skills to be aware about their rights and responsibilities. Situation has found very much worse since last ten years. Within this period, coordination and cooperation between DFO and CFUGs has found almost nil. Although, some NGOs have kept themselves touching with users, but however, no significant achievements have been realized in course of good governance. Federations of Community Forest User Groups Nepal (FECOFUN) and Surya Social Service Sector (4S) have found approaching their services into the study area.

\section{Problems and Constraints}

Given time to complete this study was a main constraint realized. Result would be more reliable and valid for whole district if more time and samples 
could have been taken for data collection. Targeted some workshops and field visits were also cancelled because of short time to inform people in the remote areas like Patracy and Guthichaur. Political conflicts and instability also affected field trips. And even more, interaction could not be held in a friendly environment. Most of the respondents were not openly taking part in discussion. A kind of fear was noticed inside them while talking about the activities they have been compelled to do against the approved rules. Field trip was also affected by snowfall. Other constraints encountered during data collection were unavailability of required official records. Most of the user groups were lacking their constitutions, operational plans and other official records. DFO also could not provide all information of all groups. Unavailability of required and related literatures in Jumla was another constraint to prepare the report in light of similar study reports.

\section{Conclusion}

In general, NTFPs are found very much associated with the rural livelihood strategy in Jumla. Majority $(57 \%)$ of the people are living under food deficit. Most of them $(>90 \%)$ are having income from NTFPs as a second source of food arrangement to sustain their livelihood. But, it does not mean that only food deficit HH involve trading NTFPs. Result clearly indicates that the people having sufficient food from their farm are also equally tapping the NTFPs as a main source of cash income. However, it differs from village to village. Villagers nearer to the collection sites of Jatamasi and Yaarchagumba earn more. The average annual income from NTFPs per $\mathrm{HH}$ is 18,565 rupees in the study area. Therefore, without any doubt, NTFP can be defined as an integral part of the rural livelihood in Jumla.

In overall, no significant correlation observed between social groups (cast) and income drawn from NTFPs in the study area. But however, direct and significant correlation is observed with sex and family size. Males are mostly involved collection and transportation of NTFPs from remote collection sites. Women look after the children, kitchen and other farm related activities and as a result they can not leave home for long time and collection of NTFPs needs at least 15 days even for the nearest village to the collection sites. Nevertheless, they play major role in processing and packaging at home. However, in low altitude, women and children also collect some NTFPs. Result clearly indicates that bigger family collect more NTFPs and earn more money than small size family. Family having more livestock (goat and sheep basically) also collect more and all types of NTFPs and earn more money because they normally spent more time in the NTFP rich areas for the pastoral activities.

Users are found to be aware about the importance of NTPF in their livelihood. But, however, most of them don't know what rights and responsibilities do they have to manage such important resources. Governance part of the CFUGs is very poor. Most of the decisions are made by chair man and majority of the users do not know what decision have been taken for what purposes. Even more, executive members although considerable numbers are included, most of the female members either do not take part or remain passive during meetings. Most of them do not know about the constitution and operational plan. In overall, users' awareness level in the study area is very low.

Most of the operational plans in the study area, although aim to manage NTFPs as a source of income, are however lacking detail about the management prescriptions of NTFPs. Although having huge potential to develop (cultivate), no initiatives have been noticed toward development (propagation and cultivation) of NTFP sector through community forestry. Very few of them are having annual allowable amount of resources to be harvested in their management plans. However, looking at existing practices, all of them are violating plans and prescriptions. Uncontrolled and immature harvesting, poor record keeping, irregular meetings and haphazard decisions are prominent in most of the CFUGs. And as a result, groups are not functioning as expected and resource degradation is going on. Jatamasi and Kutki for example are important and valuable species in the study area found depleting significantly. But nevertheless, it does not mean that no things have been started so far. Some groups, although are still negligible, have started their own system to control immature and over harvesting of NTFPs. Regarding existing awareness level, CFUGs need external supports to manage groups and their resources in a sustainable basis. However, neither DFO nor other related NGOs at present are providing such supports to them significantly.

First and significant gap is realized between management objectives and management 
prescriptions of the CFUGs' operational plans. Management prescriptions are not compatible with management objectives and that means are not compatible with the needs and interests of resource dependent users. Unavailability of resource information is another apparent gap towards sustainable management of community forests in the study area. Despite simple statement, CF management plans are lacking reliable information about the growing stock of different NTFP species. Similarly, a significant gap has also been realized in between existing and required skills to manage user groups and corresponding resources. Existing knowledge and skills of users' may not lead CF towards livelihood promotion through sustainable NTFP management. Furthermore, apparent coordination gap between users and supporting agencies i.e. DFO, NGOs has also been realized in the study area.

\section{Recommendations}

- Inventory of NTFP must be undertaken to develop resource map of the district that can serve as an information bank of different NTFP species, their natural habitats, ecology, production capacity, potential to domestication, and market values.

- District level Forestry Sector Plan (DFSP) must be developed on the basis of the resource map to ensure sustainable management of NTFPs. Sustainable NTFPs management in Jumla context should deal with income generation and poverty reduction through optimum use of the resources without jeopardizing production capacity. DFSP should explore possible options to improve production from the wild and domestication through improved harvesting technologies.

- NTFPs should be included as an integral part of the community forest operational plans to promote sustainability of resource and livelihood of resource dependent people.

- Existing CF operational plans should be revised periodically regarding ecological condition of the valuable NTFPs such as Jatamasi, Kutki and Atis in the natural habitat.

- NTFP rich forest and pasture lands should be given higher priority while handing over community forests.

- Process of monitoring and evaluation of CFUGs and other related stakeholders should be established to facilitate smooth implementation of rules and regulations.

- Awareness campaign regarding policy, good governance, users' rights and responsibilities of all CF stakeholders must be launched throughout the districts.

- Trainings and other skill development activities should regularly be conducted to improve technical skills of forest user groups. Priority should be given towards in-situ management, cultivation, harvesting, post harvesting, processing and marketing.

- Communication, coordination, and linkages between CFUGs and other organizations (GOs \& NGOs) involved in NTFP development should be established.

- Equitable distribution of benefits should be ensured within CFUGs by empowering women and other disadvantaged sub-groups. Sub groups of such disadvantage people should be formed and assigned certain area of community forests to them with a complete package of support to empower their socioeconomic condition in long run.

\section{References}

Bhandari, N. B. 2003. Cultivation and Domestication of NTFPs: An Experience from Jumla,Nepal. The Nepal Journal of Forestry, NTFPs special edition/ Vol.XII No.2/NFA 33$38 \mathrm{p}$.

CECI 1997. Non-timber forest products in Nepal: opportunities for sustainable harvesting and income generation in Jumla.

DFO Jumla, 2002. Fifth year working plan for District Forest Office Jumal 2059-2064.

Edwards, D. M. 1994. Non Timber Forest Products and Community Forestry. Project report G/ NUKCFP/12-36p.

Edwards, D. M. 1996a. Non Timber Forest Products from Nepal: Aspects of the Trade in Medicinal and Aromatic Plants. FORESC Monograph 1/96, Forest Research and Survey Center, Ministry of Forest and Soil Conservation, Kathmandu, Nepal

Edwards, D. M. 1996b. Non Timber Forest Products and Community Forestry: Are they compatible? Banko Janakari 6 (1) 3-8. 
Gurung, S. B. and Pandey, S. S. 2003: Study on Sustainable Livelihood based Bio-diversity Conservation, with a focus on NTFPs' Enterprise Approach in Nepal. The Nepal Journal of Forestry, NTFPs special edition/Vol.XII No.2/ NFA 39-54

Hertog, W.den. 1995. Hidden values: NTFPs in Dolpa District. KLDP/ Netherlands Development Organization (SNV-Nepal), Kathmandu.

Hobley, M. \& Shah, K. 1996. What makes a local organization robust? Evidence from India and Nepal. ODI Natural resource perspective series, no. 11.

Karki, S. 1996. Investigating non-timber forest products (NTFPs) oppretunities in Nepal. Nepal Austrslia Community Foresstry Projects. Cited in Subedi, B.P. 2003. Non-Timber Forest Products Sub-Sector in Nepal: Opportunities and Challenges for Linking the Business with Biodiversity Conservation. The Nepal Journal of Forestry, NTFPs special edition/Vol.XII No.2/ NFA 18-32p.

Malla, S. B., Shakyya, P. R, Rajbhandari K. R., BBhattarai, N.K, Subedi, M.N. 1995. Minor forest products (NTFPs) of Nepal: General status and trade. FRIS Project Paper No. 4. HMGN/ FINNIDA $27 \mathrm{p}+$

MFSC, 2004. Forestry sector: achievement and Oppretunities. A paper presented at Nepal Development Forum

Ojha, H. R., Subedi, B. P. and Dangal, S. P. 2003. Management of Non-Timber Forest Products:Recent Innovations in Resource Assessment and Sustainable Harvesting. The Nepal Journal of Forestry, NTFPs special edition/ Vol.XII No.2/NFA 55-65p.

Ostrom, E. 1999. Self governance and forest resources. CIFOR occasional paper No. 20.
Pandey, S. S. 2000. An assessment of NTFPs in Community Forest/Potential Community Forest in High altitude areas. A dissertation paper for B.Sc. Forestry Degree in Institute of Forestry Pokhara, Nepal.

Pattton, M. Q. 1988. How to use qualitative methods in evaluation.UAS:SAGE Publications.

Pokheral, B. K. 1998. Common property regimes: the criteria to assess their effectiveness. Paper presented in workshop on sustainable forest management, Pokhara, Nepal

Sharma, P. 1996. Non -wood forest products and integrated mountain development: Observations from Nepal. Business Seminar on Medicinal Herbs, Essential Oils and Other Non Timbers Forest Products, Kathmandu, December 1996. DEG/NGCCI. 11pp.

Subedi, B. P. 1997. Utilization of non-timber forest products: Issues and strategies for environmental conservation and economic development. Theme paper presented in the workshop on "The Utilization of NTFPs for Environmental Conservation and Economic Development in Nepal" organized by ANSAB on March 29, 1997 in Kathmandu.

Subedi, B. P. 1999: Socio-economic and institutional impact of community based ecosystem management project in Humla Nepal. Socioeconomic monitoring report to BCN. ANSAB/ Enterprise Works Worldwide.

Subedi, B. P. 2003. Non-Timber Forest Products SubSector in Nepal: Opportunities and Challenges for Linking the Business with Biodiversity Conservation. The Nepal Journal of Forestry, NTFPs special edition/Vol.XII No.2/NFA 18-32p.

USAID, Global Conservation Program (GCP) 2003. Mid Term Evaluation Report of Enterprise-Based Biodiversity Conservation_Nepal Project. Implemented by EWW and ANSAB. 